\title{
Menelusuri Sejarah Perjalanan Nomaden Bangsa Israel
}

\author{
Fredy Simanjuntak ${ }^{1} *$ Ronald Sianipar, ${ }^{2}$ Agustinus Sihombing ${ }^{3}$ \\ Prodi Teologi, STT Real Batam \\ Prodi Teologi, STT Real Batam \\ Prodi Teologi, STT Real Batam \\ fredygrace@gmail.com
}

\begin{abstract}
Tracing the travel history of the nation of Israel is the result of research to obtain some information about the beginning of this nation's vocation in the Old Testament and historical actors from various patriarchs. The history of the nation of Israel has significance because of the limitations of written documents. There is a lot of information about the past still scattered or escaped from the record, while the lifespan of the resource persons is limited. However the history of the nation of Israel will enrich the previous literature as an important summary in relation to God's chosen people with the religious life which is the continuity of the religious life of the church today. The research method in this paper uses literature studies related to historical source literature. The purpose of this research is to enrich the writing of history in a substantive manner which can be used as a source for anyone who wishes to conduct historical research, and in general for the development of science. Oral history that is handled well will provide unlimited information in numbers / pages, often even giving rise to information that has not been written in writing. This has become a concern and is also a first step for the Theology Department of STT Real Batam to write and collect collective memory in an effort to save these historical sources. The loss of oral historical sources in one generation is a great loss in the writing of history. Keywords: History, Travel, Nomads, religious, Israel
\end{abstract}

\footnotetext{
Abstrak

Menelusuri sejarah perjalanan bangsa Israel merupakan hasil penelitian untuk mendapatkan sejumlah informasi tentang awal panggilan bangsa ini dalam Perjanjian Lama dan pelaku sejarah dari berbagai para patriakh. Sejarah perjalanan bangsa Israel memiliki arti penting oleh karena keterbatasan dokumen tertulis. Ada banyak informasi tentang masa lalu masih tercecer atau lolos dari pencatatan, sementara itu usia hidup dari para narasumber terbatas. Bagaimanapun juga sejarah bangsa Israel akan memperkaya literatur-literatur yang ada sebelumnya sebagai sebuah rangkuman yang penting dalam kaitannya sebagai bangsa pilihan Allah dengan kehidupan keagamaan yang merupakan kontinuitas kehidupan keagamaan gereja saat ini. Metode penelitian dalam paper ini menggunakan studi pustaka terkait literature-literatur sumber sejarah. Tujuan dari penelitian ini adalah untuk memperkaya penulisan sejarah secara substantive yang dapat dipergunakan sebagai sumber bagi siapapun yang hendak melakukan penelitian sejarah, dan pada umumnya untuk pengembangan ilmu pengetahuan. Sejarah lisan yang ditangani dengan baik akan memberikan informasi yang tidak terbatas dalam jumlah/halaman, bahkan sering memunculkan informasi yang belum termuat secara tertulis. Hal inilah yang menjadi kepedulian dan juga merupakan langkah awal bagi Departemen Teologi STT Real Batam untuk melakukan penulisan dan pengumpulan memori kolektif sebagai upaya menyelamatkan sumber sejarah tersebut. Hilangnya sumber sejarah lisan dalam satu generasi merupakan kerugian yang besar dalam penulisan sejarah.

Kata Kunci: Sejarah, Perjalanan, Nomaden, Keagamaan, Israel
} 


\section{PENDAHULUAN}

Sejarah Israel adalah sejarah bangsa yang panjang dan rumit. Termasuk perjalanan bangsa ini berbaur dengan bangsa-bangsa lain dalam waktu yang relatif panjang. Israel sebagai bangsa dan umat pilihan Allah dilatih untuk beradaptasi dengan dunia sekitarnya. Struktur masyarakat serta kekerabatan dalam suku-suku mengalami pencampuran dari proses pembauran dengan bangsa lain.

Termasuk system peribadahanpun mengalami pengaruh dari percampuran tersebut. Secara jelas hal ini dapat ditemukan dari corak-corak peringatan oleh para Nabi dalam pengabaran mereka dalam pelarangan penyembahan berhala. Oleh karena itu penulis mencoba membatasi tulisan ini berdasarkan sejahar Israel perkiraan tahun 1300 -ketika bangsa Israel berdiam di Palestina dalam kondisi berperang terhadap musuh-musuhnya sampai kepada ditemukannya kitab Ulangan oleh para pekerja di Bait Allah sekitar tahun 622 SM. Sejak saat itu dimulai reformasi Yosia dengan penemuan kitab Ulangan yang merupakan awal terbentuknya kelompok redaksi deutronomis.

Tidak dapat dipungkiri pokok- pokok pembahasan utama mengenai bangsa Israel mengandung segmen politis, hidup social kemasyarakatan, pola kekerabatan dan keadaan ekonomi. Namun perlu dibatasi tulisan ini kea rah kesatuan Israel sebagai suatu bangsa, akan bagaimana hal-hal di atas juga dipengaruhi oleh pemerintahan kerajaan yang terbentuk di kemudian hari.

Allah memberi Tanah Kanaan sebagai warisan dengan maksud menjadikan Israel sebagai contoh dan Allah secara khusus membangunnya menjadi bangsa yang beribadah kepada-Nya. Di dalam perihal peribadatan itulah termaktub seluruh rahasia kebahagiaan, hakikat berkat Allah atas umat Israel- berupa kesejahteraan dan ketentraman dari bahaya serta ancaman, nafkah yang cukup beserta sentosa untuk beranak cucu seperti yang dijanjikan Allah sendiri. Kira-kira pada tahun 1200-900 SM masa periode kitab Keluaran dimana bangsa Israel mulai mendiami tanah Kanaan dan memulai suatu struktur masyarakat yang baru. Model hidup sebelumnya secara seminomad perlahan-lahan tergantikan dengan pola hidup baru dengan bartani.

Dokumentasi dari kitab suci juga membenarkan tentang "perang suci" namun istilah ini harus hati-hati digunakan, walupun demikian memang tidak dapat ditampik bahwa gagasan perang suci ini terlihat dari aktivitas bani Israel setelah mereka keluar dari padang gurun.

Sejak saat itu mulailah perkembangan pengetahuan dan kepercayaan kepada Allah menjadi pembebas rombongan suku-suku yan teraniaya. Sebagai penyelamat ataupun pembebas, Allah mengikat seluruh suku-suku Israel menjadi suatu perhimpuan bagi-Nya. Israel dalam pengalamannya diperkuat melalui peperangan dan kemenangan. Itulah 
sebabnya ikon-ikon keagamaan seperti arca kerub serta tabut perjanjian merupakan symbol penting dalam peperangan-peperangan tersebut.

Namun dibalik dari kehidupan bangsa Israel tersebut, Allah menginginkan bangsa yang beribadah kepada-Nya. Artinya Allah mengharapkan suatu perserikatan suku-suku, kaum, Bahasa dan secara individu yan hidup secara bersama; dengan maksud tidak ada yang terpisah dalam kegiatan dan tujuan masing-masing. Israel hendaknya menjadi suatu umat yang seluruh kelompoknya hidup dalam kerukunan sebagai keluarga besar. Umat diartikan sebagai "keluarga, kaum, kerabat, sanak keluarga yang berasal dari Bahasa Semit (Ibrani).

Ketika bangsa Israel mulai mendiami negeri atau tanah Kanaan, perhatian mereka mulai berfokus kepada kota yang disebut Yerusalem atau Sion. Kota ini terkenal sebagai pusat kerjaan dan disebut sebagai ibukota kerajaan Allah. Dalam seluruh Perjanjian Lama Yerusalem disebutkan sebanyak $669 \mathrm{kali}$, dan Sion disebut 200 kali. Dengan dmikian jelaslah bahwa kota ini merupakan kota keramat yang begitu sentral dalam kehidupan orang Israel. Kitab Suci menuliskan berulang-ulang bahwa Yerusalem merupakan kota yang Allah pilih.

Campur tangan Allah dalam pemilihan Israel tidak terlepas dari tindakan-Nya, Pengangkatan Raja-raja adalah perbuatan-Nya, terutama pemilihan Daud, (Bandingkan 2 Taw. 6:6; 1 Raja 8:16). Yerusalem memiliki peranan penting dalam hubungannya dengan tema keumatan Allah Israel. Dimana karakteristik ketepatan dan kesejahteraan kota itu bergantung hanya pada kehadiran Allah. Pada dasarnya Yerusaelm atau Sion bersifat tidak tetap, semua sifat-sifat yang melekat kepada Yerusalem seperti "gunung batu, kubu pertahanan, kota benteng, tempat perlindungan adalah symbol dari keberadaan Allah ada disana. Dan kepercayaan umat Israel semata-mata bergantung kepada berdiamnya Allah di bangsa itu. Oleh sebab itu, bangsa itu harus kudus seperti yang tertulis dalam (Imamat 19:2). Artinya, ini merupakan hal paling biasa yang ditemukan dalam hubungan bangsa Israel dengan Allah.

Jadi dapat dikatakan bahwa tidak akan ditemukan pola etika dalam Perjanjian Lama yang bertitik tolak dari perseorangan/pribadi sebagai elemen dasar dalam sejarah Allah dengan umat-Nya. Komunitas tersebut menjadi rujukan Hukum Allah diperuntukkan kepada setiap perorangan yang terdapt dalam komunitas itu. Tetapi tidak dapat dikatakan bahwa Perjanjian Lama hanya berbicara mengenai kolektivisme. Sebagaimana persoalan dekalog tertuju kepada individu atau kepada pribadi orang-orang sebagai suatu keseluruhan dan hanya dapat dilihat dengan jelas dengan begitu jelasnya seruan kepada seseorang dibentuk kepada dalam seruan kepada semua umat Israel.

Kelahiran umat Israel adalah saat pembebasan di tanah Mesir, ditetapkan (dikuduskan) pada waktu penyataan di Sinai, dan memperoleh bimbingan dalam perjalanan melewati padang gurun. Babak baru dimulai berdasarkan pembagian tanah Kanaan dan pendudukan sebagai awal fase kedewasaan umat tersebut. Sebagaimana gambaran para 
nabi mengenai Israel seperti pokok anggur: Allah mengambilnya di Mesir, kemudian menanamnya di Kanaan, dengan maksud dari sana ia menjadi berbuah-buah (Yesaya. 5:17; Yerermia 2:21; Mazmur 80:9).

Awalnya bangsa ini bergaul dengan bangsa-bangsa penduduk asli tanah Kanaan. Menuruni daerah pegunungan yang pertama sekali diduduki, berbaur dengan masyarakat kota-kota di tanah yang lebih subur. Memperhatikan upacara-upacara serta kuil-kuil yang menarik perhatian mereka; kelihatannya orang-orang asing itu juga merupakan bangsa bertuhan seperti mereka. Dalam kekaguman bangsa Israel terkadang ada upaya untuk membuka diri, menerima dan mengambil alih ciri-ciri agama orang Kanaan tersebut. Memang tidak dapat dihindari system peribadahan orang Israel sendiri banyak dipengaruhi oleh unsur-unsur peribadahan orang Kanaan. Memang cukup mengherankan juga, melihat bagaimana unsur-unsur ibadah orang Kanaan itu banyak diadopsi oleh Orang Israel sendiri yang menunjukkan seolah-olah Israel tidak pernah belajar beribadah kepada Tuhan Allah.

\section{METODE}

Penulisan artikel ini menggunakan metode penelitian kualitatif dengan penyelidikan literatur yang menguraikan tentang campur tangan dalam Panggilan bangsa Israel. Pendekatan yang dilakukan adalah dengan meninjau perjalanan nomaden yang bermula sebagaimana ditulis di dalam Kitab Kejadian. Bagaimana perjalanan bangsa Israel dalam Perjanjian Lama dilakukan? Bagaimana sejarah perkembangan kerajaan dan praktekprakter keagamaan di zaman ini memaknai asal-muasal kehidupan keagamaan yang khas dalam sebuah perjalanan yang nomaden? Apakah makna yang terkandung dalam kekhasan perjalanan tersebut memiliki hubungan dengan kehidupan keagamaan gereja di zaman ini?

\section{HASIL DAN PEMBAHASAN}

\section{Bangsa Israel Masuk di Jalan yang Nomaden}

Dilihat dari peredaksian final kitab Amsal, valid disekitar abad ke-5 hingga ke-3 SM, jika dilihat materi didikan pada kitab Amsal ada yang bersumber dari masa sebelum kerajaan terbentuk (abad 13 SM), namun panyalinan, perangkaian dan peredaksian secara secara besar-besaran pada materinya baru dikerjakan pada abad ke-8 SM. Terlebih lagi bahan kitbag Amsal merupakan kitab yang paling banyak membahas perihal ekonomi kebangsaan yang bersumber dari masa ini. Sebab itu diskusi mengenai seluk-beluk social ekonomi Israel disampaikan beersumber pada sekitar abad ke-8 SM.

Di abad ke 13 SM, tatkala kehidupan bangsa Israel dalam masa semi nomaden, kesatuan setiap anggota menjadi keutamaan. Pusat kesatuan ini berkiblat pada kepala keluarga, yang dilandasi oleh pengakuan harta milik sebagai kepemilikan bersama, dan didapat lewat kerja keras dan perjuangan secara bersama-sama (melalui peperangan) yang 
pada hakikatnya merupakan berkat Tuhan. ${ }^{1}$ Tentulah masalah kemiskinan dalam corak masyarakat seperti ini ini bukan diartikan sebagai masalah ketidakadilan social, sebaliknya merupakan masalah personal dan bukan merupakan bentuk penindasan kepada si miskin oleh si kaya.

Pola hidup semi nomadik ini bertransisi menjadi kehidupan persekutuan kesukuan yang secara tidak langsung memudarkan nilai kesatuan, disebabkan oleh perkumpulan tidak lagi didasari pada kepala-kepala keluarga tetapi pada kelompok perkota kecil atau daerah, disesuaikan dengan penerimaan berdasarkan pembagian atas tanah Kanaan. Mulailah timbul rivalitas individualistis. Tadinya kemiskinan merupakan hal yang bersifat kebetulan karena kemungkinan kepemilikan akan tanah yang kurang subur, selanjutnya dipicu oleh factor lain seperti kurangnya modal, sehingga keadaan in menimbulkan garis pemisah yang cukup lebar antara golongan yang kaya dengan golongan miskin. ${ }^{2}$

Awal dari timbulnya kemiskinan disebabkan oleh ketidakadilan social yang bermula dari masa Kerajaan dikarenakan munculnya garis kebijakan nasionalis dan centralis. Garis kebijakan menyebabkan orang-orang pusat menjadi penguasa dan menjadi pengusaha bagai perusahaan-perusahaan yang disentralir sekaligus. Sehingga menimbulkan penguatan pada golongan pusat dan pelemahan pada rakyat jelata. Oleh karena itu jurang pemisah antara golonga norang kaya dan miskin semakin dalam. Di masa pertengahan awal abad ke-8 SM, Kerajaan Israel Selatan dan Utara menjalani transisi yang sangat dramatis yang menempatkan kedua kerajaan tersebut berada di puncak kakayaan dan kekuasaan. ${ }^{3}$ Dalam keadaan seperti yang dijelaskan di atas perdaganan internasional dengan Fenisia dan Arabia mengalami kemajuan. Namun faktanya perdaganan internasional ini hanya memberi keuntungan bagi golongan elit yang memiliki pengaruh kepada para penguasa negara yang memanfaatkan kekuasaan mereka rakyat jelata ditindas oleh kepentingan golongan tersebut. Di satu sisi golongan elit semakin kaya, sebaliknya rakyat jelata semakin tertindas dan semakin miskin. Sehingga semkain menyulitkan rakyat jelata untuk mampu melepaskan diri dari ikatan kemiskinan dan penindasan. Golongan miskin dianggap hina dan tidak memiliki hak yang sama dengan golongan kaya dan wajar untuk diperas. ${ }^{4}$

Selanjutnya di masa pertengahan kedua abad ke-8 SM, kejahatan dan ketidakadilan merajalela dalam kedua kerajaan ini. Mulai timbul kelompok-kelompok yang saling menentang dan menghancurkan kesatuan yang sudah memburuk. Undang-undang dan peraturan-peraturan formal tidak lagi berwibawa. Kehidupan dan kekayaan tidak lagi tetap dan bertahan. ${ }^{5}$ Kedua kerajaan semakin melemah, sewaktu-waktu berpotensi mengalami

\footnotetext{
${ }^{1}$ John C England, Living Theology in Asia (London: SCM Press, 1981).172

2 Johannes Verkuly, Contemporary Missiology (Grand Rapids: Wm. B. Eerdmans Publishing Company, 1978). 262

${ }^{3}$ Stanley N Gundry and Alan F Johnson, Tensions in Contemporary Theology (Grand Rapids: Baker Book House, 1976).397

${ }^{4}$ John Jefferson Davis, Theology Primer (Grand Rapids: Baker Book House, 1981).63

${ }^{5}$ Prestia, Himpunan Bahan Study Institute: Contextual Exegesis Di Ujung Pandang (Ujung Padang, 1980). 20
} 
kehancuran oleh bangsa lain baik Asyur dan Babilonia siap untuk dihancurkan oleh bangsa asing, yaitu Asyur dan Babilonia. Dan kehancuran itu memang terjadi.

Genesis is the beginning of God's revelation and shows in miniature the themes that influence the rest of the Bible. ${ }^{6}$

Kitab Kejadian adalah awal dari wahyu Allah dan menunjukkan miniatur tema yang mempengaruhi sisa alkitab.

Ini membentuk dasar untuk mengajar banyak karakter dan tujuan Allah, umat manusia yang diciptakan menurut gambar Allah sebagai wakilnya, baik sebagai individu dan sebagai masyarakat, ketidaktaatan manusia dan janji keselamatan. Otoritas universal Allah dan aksesibilitas ditentukan oleh-Nya menjadi pencipta. Allah adalah adil untuk semua orang, termasuk kedua penggembala dan petani. Episode Abel dan Cain menolak asumsi umum bahwa pemburu-pengumpulan adalah negara evolusi primitif manusia, dan lebih 'maju' petani yang dihukum. Sikap kultivator terhadap peternak adalah masalah, daripada pengorbanan-Nya (Kej 4: 6-7).

Some Biblical scholars suggest that the patriarchs were not nomads by arguing that true nomadism did not develop until the first millennium BC, that is centuries after Abraham. ${ }^{7}$

Beberapa sarjana Alkitab menunjukkan bahwa para leluhur tidak nomaden dengan menyatakan bahwa nomadisme benar tidak berkembang sampai milenium pertama SM, yaitu abad setelah Abraham.

Namun, ini hanya berlaku jika satu mengidentifikasi nomadisme terlalu dekat dengan yang nanti orang Badui menggunakan unta. unta mungkin dijinakkan di SM milenium kedua untuk memfasilitasi perdagangan kafilah antara berbagai peradaban dari Mediterania timur, terutama untuk perdagangan kemenyan dari Arabia selatan.

In the biblical period camels were used for slow transport across the desert and the biblical Midianites may have had to dismount to fight (Idg. 6:4-5). Later when the camel saddle had been developed, desert pastoralism was able to develop, but only as the pressure arose to do so ${ }^{8}$

Pada periode alkitabiah unta digunakan untuk transportasi lambat melintasi padang pasir dan orang Midian Alkitab mungkin memiliki untuk turun melawan (Idg 6: 4-5).. Kemudian, ketika pelana unta telah dikembangkan, gurun pastoralism mampu mengembangkan, tetapi hanya sebagai tekanan muncul untuk melakukannya.

\footnotetext{
${ }^{6}$ Elmer A Martens, God's Design: A Focus on Old Testament Theology (Grand Rapids: Baker Book House, 1981).40

${ }^{7}$ Alan R Millard and Donald J Wiseman, "Essays on the Patriarchal Narratives" (Leicester: Inter-Varsity Press, 1980); Donald John Wiseman, They Lived in Tents in Biblical and Near Eastern Studies (Grand Rapids: Wm. B. Eerdmans Publishing Company, 1978).

${ }^{8}$ Michael Asher and Mariantonietta Peru, The Last of the Bedu : In Search of the Myth (New York: Penguin, 1997); Thomas Jefferson Barfield, The Nomadic Alternative (Amerika Serikat: Prentice Hall, 1993 ).62
} 
What concerns us is that at the beginning of the second millennium before Christ and throughout biblical times there were traveling peoples, including the ancestors of the later Bedouin, who supported themselves with cattle, sheep and goats on the steppe near to settled populations, and not living in the desert like the later Bedouin who would rely on camels. ${ }^{9}$

Apa yang menjadi perhatian kita adalah bahwa pada awal milenium kedua sebelum Kristus dan seluruh zaman Alkitab ada bepergian bangsa, termasuk nenek moyang Badui kemudian, yang mendukung diri dengan sapi, domba dan kambing di padang rumput dekat populasi menetap, dan tidak hidup di padang pasir seperti Badui kemudian yang akan mengandalkan unta-unta.

\section{Kehidupan Ekonomi Umat Allah Pasca Menetap di Kanaan}

Saat Orang Israel mendiami tanah Kanaan, dan telah meninggalkan kehidupan perbudakan Mesir, mereka memanfaatkan pertanian sebagai cara yang utama dalam mencari nafkah. Biji-bijian menjadi tanaman yang sangat penting sebagai bahan untuk membuat roti. Budidaya kacang polong dan lentil memang diketahui sudah menjadi budidaya sejak zaman prasejarah di Palestina. Petani Israel tidak seperti petani Mesir dan Mesopotamia yang harus bergantung pada irigasi air. Sekalipun di Palestina musim hujan agak pendek dan kondisi tanah berbatu, para petani di Israel memahami cara membersihkan dan memupuk lahan tanaman yang baik untuk produksi jagung. Para petani ini mempelajari dan menyesuaikan dengan siklus tahunan untuk menanam tanaman. Mereka juga menyesuaikan tanaman terbaik sesuai kondisi tanah, bukit berbatu, tanah subur, dan daerah semi-tandus. Dengan berjalannya waktu, pengalaman dan pengetahuan mereka berguna untuk menolong mereka menanam buah-buahan termasuk kurma, melon, anggur, bauah ara dan zaitun.

Desa-desa Israel dibangun oleh pemukim Kanaan yang berada di puncak bukit. Kumpulan mereka yang cukup kecil, mungkin 400 orang di terbesar ini berada di Shiloh atau Gibeon, misalnya. kota-kota ini sebagian besar tidak berkubu, meskipun mereka adalah bagian dari unit politik yang lebih besar atau kepala daerah yang memberikan keamanan. Desa-desa Israel dalam suatu wilayah yang diberikan adalah subyek dari kota utama daerah, beberapa di antaranya, seperti Sikhem, yang sangat besar dan wilayah yang cukup terkendali.

Israel diam di rumah tangga ka dung pada masa Hakim Alkitab, sering dengan keluarga mereka di cluster rumah di sekitar halaman umum. Rumah terbuat dari bata merah dengan dasar batu. Ruang hidup rumah terdiri dari tiga atau empat kamar, sering dengan

\footnotetext{
${ }^{9}$ K. R. Veenhof Universitas Michigan, The World of The Bible, ed. A. S. van der Woude and M. J. Mulder (Wm. B. Eerdmans Publishing Company, 1986)pp 234-239 ; John Bright, A History of Israel (London: SCM Press, 1972). 80
} 
ruang tidur di atap atau di atap loteng tertutup. Salah satu yang pertama-lantai kamar mungkin halaman untuk hewan lokal, sebagian besar domba dan kambing.

Tanaman tumbuh mempengaruhi ekonomi dan kehidupan sosial masyarakat. Misalnya, beberapa festival keagamaan besar di Israel - Panen Raya dan Festival Pondok disesuaikan dengan siklus pertanian. Panen Raya, juga disebut juga sebagai perayaan Minggu, ini merupakan perayaan panen gandum di musim semi (Keluaran 23, 16). Hari raya Pondok (atau Pondok Daun) adalah hari libur musim gugur untuk kesempatan penanaman dan pengumpulan tanaman, dan panen tahunan.

Sebuah fitur yang menakjubkan dari kehidupan Israel adalah tahun sabatikal, satu tahun di setiap tujuh ketika petani akan membiarkan sisa tanah. Ini merupakan pola kerja yang diikuti system kerja enam hari dalam satu minggu yang sesuai dengan perintah Allah untuk menguduskan hari sabat atau hari ke tujuh sebagai hari peristirahatan masing-masing (Kel 23,10-12). Selain itu, hari sabat ini sebenarnya mempunyai manfaat praktis dalam meningkatkan kesuburan tanah dalam jangka panjang.

Orang-orang juga mungkin telah berlatih rotasi tanaman, lebih meningkatkan tanah (Yesaya 28, 23-29). Cara tertib di mana petani tumbuh tanaman mereka adalah untuk mencocokkan rencana Allah bagi orang-orang Israel dan untuk kebaikan ciptaan. Dari perspektif agama, namun, Ulangan menjelaskan bahwa panen raya juga tergantung pada bagaimana orang-orang Israel menaati perintah-perintah Allah (Ulangan 11,10-17).

Transisi kehidupan dari pengembaraan menjadi hidup menetap menghadirkan perubahan system tantan masyarakat yang besar. Sanak keluarga mendiami perkampuangan dan kota kecil. Dari sinilah mulanya adanya tanah milik. Tanah yang ditempati dan yang juga belum ditempati, dan dibagi-bagi menurut kaum kepada masingmasing suku melalui pengundian (Yosua 13-21; bandingkan. Hakim-hakim 1). Pembagian tidak dilakukan berdasarkan status namun berdasarkan kebutuhan akan besarnya masingmasing kaum (Bilangan 33:54). Memang secara general tanah yang dibagikan merupakan milik bersama kaum yang menerimanya, hanya dalam bagian tertentu masing-masing keluarga bertanggungjawab untuk pemeliharaannya.

Namun ada kecenderungan adanya hak milik pribadi dalam masyarakat yang menetap. Misalnya, dalam hal rumah yang didirikan dan tanah yang ditanami seseorang ataupun suatu keluarga tentunya ada perasaan kepemilikan secara istimewa karena tanah yang diusahakan tersebut. Pada akhirnya system kepemilikan tanah oleh menjadi hal biasa di Israel, seperti yang dipahami di zaman kerajaan (Bandingkan, Raja-raja 4:25; Mikha 2:2).

Perkembangan hak milik tanah pada akhirnya menimbulkan perbedaan yang semakin besar di masyarakat. Sebagaimana dalam masing-masing keluarga ada kepemilikan tanah yang tidak sama tingkat kesuburan maupun kecakapan yang berbeda dalam pengelolaan tanah. Kemungkinan lain adalah adanya bencana alam yang terjadi di tempat tertentu sementara di tempat lain petani memiliki hasil yang berlimpah yang mengakibatkan sebagian menjadi semakin kaya dan lainnya menjadi semakin miskin. 
Sekalipun disebabkan oleh perubahan-perubahan seperti di atas, hak tanah tetap berhubungan secara erat dengan kaum keluarga, karena dipandang sebagai pemberian dari Allah kepada mereka dalam hal penggenapan janji-Nya kepada nenek moyang mereka, Abraham. Itulah sebabnya tanah tidak diperjualberlikan seperti barang dagangan. Dalam hal misalnya disebabkan oleh kemiskinan maka seorang petani dengan keadaan terpaksa harus menjual tanahnya, maka ada kewajiban sebagai pembelinya haruslah kerabat atau keluarga terdekat supaya tanah tersebut tetap sebagai milik kaum keluarga (Rut 4:3-4). Dengan begitu jurang pemisah antara si kaya dan si miskin dapat dihindari. Pada awalnya di Palestina (zaman para hakim) orang-orang Israel berdiam di daerah perbukitan yang terpisah dari kota-kota orang Kanaan di tanah datar, yang mejadikan pusat ekonomi mereka dengan bertani. Sebuah gambaran kehidupan bertani tanpa perdagangan dan arus urbanisasi. Dalam suasana seperti ini kesenjangan antara orang kaya dan miskin tidak terjadi. Jika dilihat rekam jejaknya dua raja Israel pertama merupakan berasal dari keluarga dengan kehidupan ekonomi sedang, keduanya diketahui sebagai pekerja biasa sebelum menjadi raja. Saul adalah peternak (1 Samuel 9:3; 11:5); Daud adalah gembala (1 Samuel $16: 11)$.

\section{Tiba Di Kanaan}

Berabad-abad sebelumnya, Allah telah mengadakan perjanjian dengan Abraham untuk memberikan tanah Kanaan kepada keturunannya. Janji ini diulangi dengan Ishak dan Yakub diperbaharui dengan Musa, diulangi kembali dengan Israel di padanggurun, dan sekali lagi ketika Yosua diperintahkan untuk memimpin mereka menyeberangi sungai Yordan. Allah berjuang untuk Israel dan memberi mereka kemenangan. Allah berjanji untuk menyingkirkan para penghuni tanah itu dari hadapan Israel (Yos. 13:2-6a). Tentang daerah yang telah direbut. Ia mengatakan, "Bagi-bagikanlah daerah itu kepada bangsa Israel sebagai tanah pusaka". ${ }^{10}$

Meskipun bangsa Israel sebagai bangsa pilihan dan Allah terlebih dahulu menjanjikan tanah Kanaan menjadi bagian milik mereka. Namun diperlukan perjuangan untuk memilikinya, bangsa ini dituntut belajar patuh dan percaya (Bilangan 1:3).

Jauh sebelum itu di zaman Yosua, tanah Kanaan sudah mulai diduduki oleh kelompok-kelompok suku Ibrani. Suku-suku ibrani awal in telah lebih dahulu bertransisi dari pola kehidupan semi nomadis ke pola kehidupan bertani ketika kelompok-kelompok yang di pimpin oleh Yosua masuk ke Kanaan. ${ }^{11}$

Setelah bangsa Israel mengikat Perjanjian dengan Tuhan Allah, mereka bersiapsiap berangkat dari Sinai. Riwayat perjalanan Israel dari Sinai sampai ke perbatasan

\footnotetext{
${ }^{10}$ W S Lasor et al., Pengantar Perjanjian Lama : Jil. 1 Taurat Dan Sejarah (Jakarta: BPK Gunung Muliah, 1993). Hh 294-94

${ }^{11}$ Theodorus Christiaan Vriezen, Agama Israel Kuno (Jakarta: BPK Gunung Mulia, 1967).161
} 
Kanaan dicatat dalam kitab Bilangan. ${ }^{12}$ Tanda-tanda akan kehadiran dan perhatian Allah terhadap bangsa Israel tampak pada pasal-pasal pertama kitab Bilangan. Kemahsyuran menjadi tanda berkat pertama. Sesuai dengan yang diperintahkan kepada Harun untuk disampaikan kepada bangsa Israel (Bilangan 6:22-27). Ada tiga bagian yang termaktub dalam janji ini: Pertama, Jaminan dasar bagai kebutuhan dan kehidupan. Kedua sebagai pengasih, Tuhan berjanji hadir secara pribadi. Yang ketiga adalah damai sejahtera dengan mengahadapkan wajah-Nya. Kehadiran Allah dalam tiang awan dan tiang api merupakan tanda kedua yang memimpin mereka dalam perjalanan di padang gurun dan sebagai pertanda bagi mereka untuk berangkat ataupun berkemah (Bilangan 9:15-23). Selanjutnya Allah menunjuk tujuh puluh tua-tua untuk bekerjasama dengan Musa dalam mengatur bangsa Israel inilah yang menjadi tanda ketiga (Bilangan 11:24-27).

Allah menyatakan memberikan jaminan-jaminan dengan kehadiran-Nya di tengah-tengah bangsa Israel ketika mereka memulai perjalanan menuju Kanaan. Namun sebaliknya bangsa Israel kerap mengeluh mengenai makanan, minuman dan daging. Mereka mendapat jawaban Allah dengan menyediakan makanan. Bahkan mereka tidak mendengar janji Allah dan ketakutan ketika didengar laporan para pengintai (Bilangan 13) dan tidak mendengarkan perkataaan Yosua dan Kaleb. Itulah yang menyebabkan bangsa ini mengalami hukuman dan mengmbara selama empat puluh tahun. Allah hanya mengijinkan anak-anak keturunan Israel yang akan melihat negeri yang Allah janjikan itu.

Israel memang perlu mengalami perjalanan padang gurun dengan tujuan penginsyafan. Tidak ada jalan lain selain bergantung kepada Allah dan menuntut penyerahan diri tanpa syarat dalam pengembaraan mereka. Bahkan pengalaman tersebut memberikan pelajaran ingat-ingatan penting bagi Israel sebagai tuntutan yang mutlak bahwa tidak ada kemenangan jika bukan karena kehendak Allah

\section{Revolusi Sosial (Pergolakan)}

Pada akhir Kitab Yosua, dinyatakan bahwa suku-suku Israel berada di tanah yang telah dijanjikan Allah kepada bapak-bapak leluhur mereka, namun mereka tidak berhasil menundukkan semua musuh-musuhnya. Mereka memang menjadi satu bangsa yang dipimpin oleh seorang raja, namun selama dua ratus tahun atau lebih, hal itu belum terjadi. Diantara masa tersebut disebut dengan "zaman para hakim". 13

Pada zaman hakim-hakim ini terdapat konsep sejarah yang berkembang dalam Perjanjian Lama, di sinilah bangsa Israel mulai terstruktur kehidupannya namun tetap saja mereka berpaling dari Allah. Allah telah membawa bangsa Israel keluar dari perbudakan Mesir untuk memenuhi perjanjian Allah yang telat diikat kepada mereka, dimana sebagian perjanjian itu disampaikan Allah melalui Malaikat-Nya di Bokhim:"janganlah kamu mengikat perjanjian dengan negeri ini, mezbah mereka haruslah kamu robohkan (Hakim-

\footnotetext{
${ }^{12}$ David L Baker, Mari Mengenal Perjanjian Lama (Jakarta: BPK Gunung Mulia, 2013).42

${ }^{13}$ Lasor et al., Pengantar Perjanjian Lama : Jil. 1 Taurat Dan Sejarah.299
} 
hakim 2:2). Namun bangsa Israel tetap saja melangar perintah Tuhan. Ketidaktaatan Bangsa Israel inilah yang dipakai Allah untuk mengajar mereka agar lebih memahami tujuan Allah dalam memilih mereka dan mengadakan hubungan istimewa terhadap mereka. ${ }^{14}$

\section{Alasan adanya Hakim-Hakim (Hakim-hakim 2:11-19)}

Adapun karena pelanggaran-pelanggaran umat Israel yang mengakibatkan mereka tidak bisa berhubungan langsung dengan Allah,dan tuntutan bangsa Israel sehingga Allah memilih orang yang dapat menjadi perantaraan Allah kepada bangsa Israel. Sebutan Hakim-hakim ini diambil dari kedua belas tokoh yang menghakimi Israel, dimana Hakimhakim itu adalah para petugas yang ditunjuk dan ditugaskan Allah untuk menghakimi atau mengadili bangsa Israel jika mereka melanggar perintah Allah. ${ }^{15}$

Periode Hakim-hakim ini meliputi transisi [Zaman Perunggu Akhir] berganti Zaman Besi Awal. Zaman ini merupakan zaman kemakmuran.Di Palestina saat itu masih menjadi negara kota yang relative kecil dan independen. Keadaan ini yang menimbulkan terbentuknya kerajaan lain, seperti Mesir dan Het. Orang Israel mendiami tanah perbukitan sementara orang Kanaan tinggal di pesisir dan dataran rendah. Israel secara relative dapat hidup tanpa diganggu oleh bangsa lain.Hal ini memungkinkan munculnya suatu kerajaan, seperti Mesir dan Het. Orang-orang Kanaan tinggal di dataran rendah dan pesisir dan orang-orang Israel di perbukitan. Mereka relatif bisa hidup tanpa gangguan dari bangsa lain. Orang Israel merupakan lawan dari orang Filistin.

Orang Flistin merupakan lawan dari orang Israel. Mereka awalnya datang dari pesisir barat tanah Kanaan. Mereka sudah menetap dan membuat tembikar. Catatan Alkitab mengenai orang Flistin digambarkan sebagai bangsa yang tidak beradab dan tak bersunat. Dagon adalah dewa utama yang disembah bangsa ini. Orang Israel memiliki kecenderungan meninggalkan Allah dan berpaling kepada dewa-dewa orang Kanaan. Hal ini disebabkan oleh keunggulan orang Kanaan dari orang Israel dalam beberapa hal, seperti: bidang kesastraaan, kesenian, arsitektur, oraganisasi, politik dan perdagangan. Kegiatan ini pun membawa orang Israel kepada praktik keagamaannya. Praktek pelacur sacral (pelacur bakti), menyembah Baal. Gabungan antara seks dan agama ini menjadi daya tarik bagi orang Israel berpaling dari Tuhan.

Masa bermukim ini digolongkan pada dua masa yang berbeda, masa hakim-hakim dan kerajaan. Berakhirnya masa kepemimpinan Yosua menandai dengan masa hakimhakim. Timbulnya masa hakim-hakim disebabkan oleh tidak memadainya kepemimpinan para tua-tua dalam situasi perang yang genting yang menjadi ancaman bagi keamanan bangsa Israel (Setelah Yosua meninggal). Tugas seorang hakim adalah menentukan keadilan sekaligus menjadi pemimpin. Biasanya hakim-hakim ini berasal dari salah satu

\footnotetext{
${ }^{14}$ Ibid.300

${ }^{15}$ Ibid.302-303
} 
dari para tua-tua yang dianggap memiliki kemampuan menjadi seorang hakim. ${ }^{16}$ Pada masa ini kepemimpinan diserahkan kepada tua-tua (kepala suku), setelah dilakukan pembagian wilayan. Selain itu juga pemimpin yang diangkat di luar dari tua-tua yang berperan selama peperangan (Yosua 23:2). Ketika hukum moral terus rusak, baik oleh individu, masyarakat, atau bangsa, keamanan palsu dapat berlangsung selama beberapa waktu, ilusi sebagai dosa itu sendiri; tetapi cepat atau lambat perilaku jahat diikuti oleh hasil kejahatan, sebagai tentu sebagai musim dingin berikut gugur. Negara yang menaruh harapannya pada para dewa besi dan baja bukan dalam Tuhan Kebenaran dan Keadilan, ditakdirkan. Lama dan Perjanjian Baru menunjukkan jalan kemuliaan nasional benar.

\section{Kerajaan terbentuk}

Kira-kira tahun 1020 SM, bangsa Israel meminta kepada Samuel seorang pemimpin (raja). Maka ketika Samuel bertemu dengan Saul ketika sedang mencari keledai-keledai ayahnya yang hilang. Saul terpilih dengan cara diundi dari kaum Matri dan Suku Benyamin. Dan Samuel pun mengurapinya menjadi seorang raja. Kerusuhan orang Amon menguji kemampuan Saul memimpin mereka dengan dasar kharisma dari Allah. Meskipun dia telah menjadi raja dan banyak dipuja-puja orang, namun dia tetap bertani. Keberhasilan Saul membuat musuh-musuhnya tunduk kepadanya. ${ }^{17}$

Orang Filistin terus-menerus menekan kerajaan yang masih muda itu, dengan memonopoli industri logam dan pemanfaatan kereta perang, mereka mampu mengungguli kekuatan militer bangsa Israel. Saul memiliki seorang anak yang bernama Yonatan. Yonatan yang terampil dan berani dengan pembawa senjatanya, membunuh begitu banyak orang Filistin sehingga keberanian Israel pulih. ${ }^{18}$

Namun karena kejayaan Saul disamping berguna bagi bangsa Israel, juga menimbulkan bahaya, banyak keputusan-keputusan yang fatal, sumpahnya yang tidak dipikirkan, ketidakpatuhan Saul yang amat mencolok terhadap Samuel menyebabkan dia tersingkir, dan Samuel pun memohon ampun namun Samuel tetap kepada keputusannya, agar dapat menjadi pelajaran dari perbuatan Saul. ${ }^{19}$

Penobatan Daud didasarkan oleh hancurnya kekuasaan Saul yang diberikan Allah, karena Saul telah berpaling dari Allah. Hal ini mengakibatkan Saul depresi. Kemampuan Daud mengalahkan Goliat yang mengangkat Daud keposisi yang penting dalam tentara Saul serta mendekatkan dengan putranya Yonatan. Saul pun menawarkan putrinya, Merab dan Mikhal dengan tujuan tertentu, dan meminta kulit khatan seratus orang Filistin, dengan tujuan agar Daud terbunuh, namun rencana Saul gagal, Daud dan tentaranya malah membawa dua kali lipat dari yang diminta Saul.

\footnotetext{
${ }^{16}$ Ignatius Suharyo Hardjoatmodjo, Mengenal Alam Hidup Perjanjian Lama (Yogyakarta: Kanisius, 1993). 68

${ }^{17}$ Lasor et al., Pengantar Perjanjian Lama : Jil. 1 Taurat Dan Sejarah.337-338

${ }^{18}$ Ibid.339

${ }^{19}$ Ibid. 340
} 
Daud dan Yonatan mengikat janji persahabatan, sementara Saul berencana membunuh Daud, dan Yonatan berulang kali menyelamatkan nyawa Daud. Namun Yonatan tidak dapat melindungi Daud terus-menerus, sehingga Daud melarikan diri. Siasat Daud dalam menghadapi Saul ialah bertahan, bukan menyerang, karena Daud memiliki kesempatan untuk membunuh Saul, namun dia tidak melakukan itu, dia hanya memotong punca jubah Saul sehingga dia menyesal telah menghianati rajanya. Namun Saul telah putus asa menghadapi Filistin tanpa mendapat bimbingan Allah, sehingga dia menjatuhkan dirinya sendiri diatas pedangnya, sehingga dia meninggal, dan orang Filistin memancung kepalanya dan mengambil senjatanya sebagai tanda kemenangan mereka dari bangsa Israel. $^{20}$

Pembentukan bangsa Israel terjadi dengan begitu cepat yang dibuktikan dengan kepemimpinan dimulai dari raja pertama Saul sampai kepada Salomo hingga kepada terbaginya kerjaan Israel dan Yehuda. Di dalam kedua kerajaan inilah mulai berbalik struktur-struktur social, politik dan ekonomi. Kesejahteraan kerajaan dan raja menjadi pokok penting dan diketahui juga adalah sebagai pertolongan Allah. Raja dianggap sebagai pemegang otoritas keilahian dengan system dinasti, sedikitnya dapat dilihat Dari keturunan Daud di Yehuda (2 Samuel 7:8-16; Mazmur 2). Pada waktu ini cita-cita ideal Kerajaan tidak terwujud seperti yang tersurat dalam Mazmur 72. Secara umum para nabi saat itu menentang ibadah yang munafik dan penindasan kepada orang lemah yang beroposisi terhadap system kerajaan secara nyata (misalnya Amos dll).

Namun pertanyaan yang penting adalah dari manakah minat bangsa Israel untuk meminta seorang raja. Sementara pada waktu itu nabi dianggap sebagai pesuruh Allah/penerjemah, pelihat dan sebagainya. Ditilik dari ilmu sejarah bangsa-bangsa kuno, Israel termasuk diantara bangsa-bangsa lain yang memakai kerajaan (monarchy) sebagai lembaga pemerintahan dan corak kehidupan masyarakatnya. Bagi bangsa Israel, kerajaan bukan hanya sebagai system masyarakat tapi juga memiliki nilai teologis, khususnya dihubungakan dengan kerajaan Abadi, yang menggambarkan Allah sendiri yang memerintah. Perbuatan-perbuatan Allah digambarkan dalam makna yang begitu besar, Allah dikenal sebagai pribadi yang menetapkan hati-Nya ketika mengangkat seorang raja sebagai pelaksana kehendak-Nya di atas bumi. Kesadaran yang demikian mulai timbul tatkala mereka mulai mendiami Kanaan, persekutuan mereka mulai terasa kendur.

Kerjasama mereka bukan hanya diperlukan saat melawan musuh tetapi juga dalam beribadah kepada Allah. Ketika mereka mulai bercocok tanam di Kanaan, hal itu semakin berkembang. Timbullah keinginan bagi mereka menjadi persis seperti bangsa lain karena system pemerintahan rapi dan kuat seperti yang mereka lihat pada bangsa Kanaan (1 Samuel 8:15), supaya mereka mampu membela dirinya di antara bangsa-bangsa di sekeliling. Namun bagaimanapun system pemerintahan seperti itu tidak juga membawa perubahan-perubahan dalam masyarakat Israel.

\footnotetext{
${ }^{20}$ Ibid.341-345
} 
Mereka harus membayar mahal demi kemajuan supaya keamanan dan ketertiban menjadi terjamin. Perubahan otonomi suku-suku dan adat serta lembaga lainnya mulai pudar dan lenyap. Sedangkan beban berat yang dipatok harus dipikul oleh masyarakat dengan membayar pajak dan kerja rodi. Selain itu kekuasaan raja dan para pejabatnya semakin meluas. Tanah-tanah dimiliki kerjaan, pergantian angkatan suku-suku dengan menyewa para prajuit dan tentara, negara terlibat dalam catur politik; hal-hal inilah yang mengakibatkan kegemparan dalam dasar-dasar kemasyarakatan Israel.

Yehuda mengalami degradasi politik dan kemunduran agamawi pada abad ke 7 SM. Setelah tahun 701 SM Asyur menguasai kerajaan Hizkia sampai kepada kerajaan anaknya Manasye sepanjang tahun 693-639, juga penggantinya Amon, yang memerintah hanya selama kurang lebih dua tahun kemudian dia dibunuh. Yehuda juga tidak mengalami perubahan intern yang signifikan selama masa pemerintahan Yosia di fase pertama pada tahun 638-609 SM, sekalipun kerajaan Asyur pada waktu itu mengalami kemerosotan, yaitu pada masa akhir kerajaan Asyur-Banipal. Israel mengalami pembauran dengan dunia sekitarnya dalam praktek keagamaan dan religiositas yang brehubungan dengan system peribadahan umat itu.

Israel bukanlah bangsa pribumi di tanah Kanaan, sehingga sepanjang sejarah mereka menyadari kenyataan tersebut. Israel berkembang menjadi sebuah bangsa dari kumpulan suku-suku Ibrani kuno. Hal ini sesuai dengan yang dijelaskan oleh Vriezen mengenai pertalian latar belakang Israel dengan leluhur Israel yang memiliki latar belakang yang kuat dengan dunia semit, Mesir, Babel, Asyur, Persia, Arab, Asia kecil dan ini terlihat sedikit banyak dalam perbedaan dan kesamaan dalam system peribadahannya. ${ }^{21}$ Sebagai contoh adanya unsur baalisme dalam tradisi Yahwisme. Dalam golongan ini, unsur terpenting yang terlihat adalah fakta bahwa Yahweh, dianggap sebagai Allah yang hidup sekaligus sebagai sumber kesuburan. Kenyataan itu ditarik dari beberapa wilayah yang begitu jauh dimana Yahweh dihubungkan dengan symbol tertentu seperti baal atau lembu, seperti kuil-kuil di Dan dan Betel (1 Raja-raja 12:26; Keluaran 32:1).

Meskipun tidak dapat dikatakan bahwa pemahaman tersebut merupakan pengadopsian secara bulat-bulat oleh orang Israel, namun pada dasarnya Allah tidak terlibat secara langsung dalam proses alamiah tersebut. Dalam peribadahannya, orang Israel pun memiliki persamaan yang terdapat pada bangsa-bangsa di sekitarnya. Bangsa Israel pada waktu itu masih menjadi bangsa yang muda, dibandingkan dengan bangsa lain seperti Mesir, Babel, Fenisia dan Kanaan yang seribu tahun lebih tua dibandingkan dengan mereka. Namun tidak berarti bahwa bangsa Israel sebagai umat Allah tidak memiliki kekhususan dalam sister peribadahannya.

Hubungan dengan Allah menjadi suatu keunikan tersendiri bangsa Israel yang merupakan hal baru dalam semangat keagamaan mereka serta menurut pandangan moral yang bermaksud memusatkan inti kekhasan Israel dalam hubungan kepada Allah. Dalam

${ }^{21}$ Vriezen, Agama Israel Kuno. 
model kehidupan agama dan pandangan moral bangsa Israel unsur-unsur ini melahirkan suatu bentuk agama yang sama sekali baru yaitu suatu bentuk pencapaian akal dan roh manusia agama dalam pandangan dunia paling agung. Barangkali, lebih tepatnya lagi, hal ini merupakan inti pemberitaan para nabi dalam hal sinkritisme, mengenai peribadahan dan religiositas orang Israel yang paling banyak dikritik. Sebelum masa pembuangan, di masa pembuangan dan setelah masa pembuangan inilah yang dilihat oleh para nabi yaitu praktikpraktik keagamaan dalam keimanan bangsa Israel yang ad pada waktu itu.

Pembentukan kerajaan menyebabkan perubahan-perubahan penting sebagai pemusatan permintahan dalam masyarakat Israel, seperti yang dinubuatkan oleh Samuel sejak awal (1 Samuel 8:10-18). Sebagai sebuah negara untuk pertama kali Israel bersatu, meliputi daerah pendudukan suku-suku di perbukitan sampai ke tanah datar dengan kotakota orang Kanaan, yang jauh berbeda gaya hidup dari suasana pedusunan di masa awal orang Israel mendiami Palestina. Kebiasaan-kebiasanaan hidup masyarakat Israel dipengaruhi oleh struktur social ekonomi Kanaan, sehingga mulailah berkembang golongan kaya dan golongan miskin.

Dalam kebiasaan ornag Kanaan, system kewarganegaraan didasari pada kepemilikan tanah, bukan pada keanggotaan suku. Lagi pula tanah bagi mereka adalah sesuatu yang yang dapat diperjualbelikan secara bebas sebagaimana halnya barang. Dengan demikian bagi orang Israel memiliki kesempatan untuk memperluas tanah milik mereka dengan membeli tanah milik orang Kanaan dan menambahkan kepada milik pusaka mereka. Sebaliknya bisa jadi keluarga Israel yang kurang mampu akan menjual tanahnya kepada orang Kanaan, akibatnya terjadilah perbedaan yang semakin besar dalam masyarakat Israel.

Orang Kanaan memiliki system hak tanah berdasarkan system feodal. Dimana kaum bangsawan menguasai susunan masyarakat. Pengembangan dan pembangunan kotakota memungkinkan adanya kemajuan di bidang militer, khususnya pemakaian kereta perang yang mahal dan memerlukan tanah yang cukup luas dalam pemeliharaan kudakuda. Kaum bangsawan orang Kanaan adalah orang-orang yang yang mahir menggunakan kereta tempur, mereka disebut ahli perang yang sebagaimana salah satu haknya adalah memiliki tanah. Demikianlah terjadinya kesenjangan terjadi antara golongan bangsawan dengan masyarakat Kanaan, orang-orang yang tinggal di kota memiliki tanah, dengan golongan petani setengah merdeka dan golongan budak yang mengerjakan tanah

Sistem feodal ini mempunyai pengaruh yang semakin dalam pada masyarakat Israel:

$>$ Pada awal kerajaan Israel, di zaman raja Saul, suku-suku dikerahkan untuk berperang sama seperti masa hakim-hakim (1 Samuel 15).

$>$ Di masa pemerintahan Daud, tentara Israel terbentuk, dengan merekrut orang-orang Israel dan juga para prajurit upahan dari luar bangsa Israel (yang bukan salah satu dari kedua belasa suku Israel namun setia kepada raja). 
> Pembentukan angkatan bersenjata selesai di zaman raja Salomo, dengan menggunakan kuda dan kereta perang (1 Raja- raja 4:26).

Sistem militer yang baru ini terpengaruh oleh system yang berlaku di Kanaan, yang hubungannya erat dengan system feodal, sehingga kesenjangan juga timbul di Israel baik antara golongan atas dan bawah sebagaimana yang dikenal di kota-kota Kanaan kuno. Sementara dalam proyek-proyek pembangunan raja Salomo mempergunakan kerja paksa (1 Raja-raja 5:13; 9:15-22). Peristiwa ini belum pernah berlaku di Israel sebelumnya. Hal ini cukup berbeda dengan raja pendahulu seperti Saul maupun Daud, yang kehidupannya masih begitu sederhana, Salomo sendiri bertambah kaya dan hidup dengan berbagai kemewahan (1 Raja-raja 10:14-29).

Pemiskinan golongan petani pada zaman kerajaan terjadi oleh berbagai macam sebab. Salah satunya disebab kan oleh sistim pemberian tanah (fief) kepada orang atau golongan tertentu sebagai ganjaran karena berjasa bagi negara atau raja, ini adalah seuatu yang biasa dalam sistim feodal dan tentunya bertentangan secara adil dalam masyarakat Israel.

Penyebab lain adalah dengan adanya bunga pinjaman yang sangat tinggi (Bandingkan, Keluaran 22:2,Imamat 25:35-37; Ul 23:19-20; Amsal 28:8). Seorang petani yang tidak punya tabungan tentunya memerlukan pinjaman untuk membeli bibit, khususnya setelah kondisi hasil panen yang buruk. Pinjaman tersebut memang cukup menolong untuk sementara waktu, tetapi pada akhirnya petani justru dua kali mengalami kerugian, pertama disebabkan oleh kondisi penen yang gagal, kedua pembayaran Bungan yang dituntut oleh pemberi pinjaman. Dengan begitu ada beberapa tahap pemiskinan ini:

$>$ Pinjaman:orang terpaksa menggadaikan pakaian atau hasil dari tanahnya kerana berhutang

$>$ Tidak mampu membayar: akhirnya ia menjadi penyewa atas tanah miliknya sendiri dan terpaksa bekerja bagi orang yang berpiutang kepadanya

$>$ Perbudakan: karena tidak memiliki apa-apa lagi dalam keadaan terpaksa menjual anaknya atau dirinya sendiri untuk menghindari kematian karena kelaparan (2 Raja-raja 4:1)

Sistim feodal telah meruntuhkan struktur masyarakat Israel yang tradisional di abad ke-8 SM. Semakin lama semakin banyak tanah yang menjadi milik suatu golongan pemilik tanah tyang hidup di kota-kota dan memeras para petani (Yesaya 5:8; Amsal 5:11;6:1-6). Perhimpunan dan persekutuan suku-suku secara praktis berakhir dan setiap orang atau keluarga mulai hidup secara individual, yang akhirnya semakin menunjukkan kesenjangan yang memprihatinkan antara si kaya dan si miskin.

Bukti arkeologi menunjukkan perbedaan tingkat hidup pada abad ke-8, seperti dalam penggalian di kota Tirza. Penemuan rumah-rumah dari abad ke-8, yang secara kontras menunjukkan rumah-rumah kecil yang didiami oleh rakyat biasa dengan rumah- 
rumah mewah orang kaya. Sedangkan di abad ke-10 di tempat yang sama tampak persamaan dalam besarnya rumah-rumah.

Israel hanya bersatu pada masa kerajaan di bawah pemerintahan Raja Daud dan Salomo. Sesudah itu Israel memasuki masa kepemimpinan dan terpecah dua (Israel utara dan selatan). Perubahan ini dipicu oleh ketidakpuasan atas kepemimpinan dari penerus Samuel. Ada tiga jabatan yang istimewa pada masa kerajaan, yaitu raja, nabi dan imam.

Dalam masa kerjaan di Israel raja berperang dalam bidang politis dan keagamaan. ${ }^{22}$ Sekalipun seorang raja diangkat berdasarkan garis keturunan, tetap seorang raja dianggap utusan Allah (Mazmur 89:3,19). Kokohnya tahta seorang raja bergantung sepenuhnya atas janji Allah (II Samuel 7). Itulah sebabnya seorang raja sering disebut sebagai anak Allah (II Samuel 7:14; Mazmur89:27). ${ }^{23}$ Sementara nabi digolongkan ke dalam dua kelompok, pelihat dan nabi yang berperan dalam kehidupan agama Israel. Para pelihat merupakan golongan yang mampu menilik dan mengetahui kebenaran mengenai masa lalu, masa kini, dan masa depan secara lebih akurat daripada orang-orang lain. Para pelihat sangat disegani di Israel karena apa yang disampaikan oleh para pelihat itu benar adanya. Baik nabi maupun rombongan para nabi biasanya hidup bersama-sama di suatu tempat ibadat. Kelompok ini tampaknya tidak selalu disegani (2 Raja-raja 9:11). Para nabi bertindak sebagai penafsir peristiwa politik, social di zamannya, sehingga sering disebut sebagai suara hati umat Allah. ${ }^{24}$ Selain berkelompok ada juga para nabi yang hidup perorangan, seperti Elia, Natan, Yesaya, Hagai, Maleakhi dan lainnya. Nampaknya yang paling cocok disebut sebagai nabi sejati adalah nabi-nabi perorangan ini. Selanjutnya untuk kegiatan ibadah kepada Allah para imamlah yang beroleh tugas memimpin umat Israel supaya ibadah dapat berlangsung secara benar dan teratur menurut aturan agamawi yang berlaku pada waktu itu. Pada awalnya Suku lewilah yang diberikan posisi sebagai imam beserta keturunannya, akan tetapi kemudian orang-orang di luar suku Lewi mulai bertugas sebagai imam seperti Zadok yang menggantikan Abyatar yang meneruskan pekerjaan imam yang biasanya dilakukan oleh bani Lewi. (1 Raja-raja 1:5-8; 2:35). Keberadaan para imam muncul sejak perjalanan bangsa Israel menuju Kanaan. Termasuk pada waktu itu sudah mulai ada golongan orang kaya dan miskin.

Keadaan social Israel terbentuk berdasarkan tingkat kebutuhan masyarakatnya bagi dari masa nomad hingga ke masa kerajaan. Dilihat dari pembahasan di atas tampak Israel mengalami perkembangan social baik secara negative maupun positif. Tingkatan social di masa Bapa leluhur terjadi karena kontras tingkat ekonomi, masa perbudakan dan masa keluarannya bangsa Israel dari Mesir. Setelah masa ini tampaknya tingkatan social tidak lagi diakibatkan oleh factor perbedaan ekonomi, tetapi factor keahlian individual dalam kepemimpinan, juga pada waktu berdiam dan menetap di Kanaan, tingkatan social dalam

\footnotetext{
${ }^{22}$ David F Hinson, Sejarah Israel Pada Zaman Alkitab (Jakarta: BPK Gunung Mulia, 2015).127

${ }^{23}$ Hardjoatmodjo, Mengenal Alam Hidup Perjanjian Lama.71-72

${ }^{24}$ C Groenen OFM, Pengantar Ke Dalam Perjanjian Lama (Yogyakarta: Kanisius, 1992).211-212
} 
masyarakat disebabkan faktor ekonomi dan juga kemampuan individual dalam memimpin. Secara umum di dalam struktur masyarakat Israel kuno terdapat tingkatan-tingkatan sosial.

Kehidupan bangsa Israel mengalami perubahan, mulai dari yang dulunya hidup secara berpindah-pindah dan bertani mereka mengalami kemajuan tidak lagi bergantung pada kesuburan tanah. Sekarang menjadi warga Negara yang kuat, tampil dalam dunia internasional baik dibidang politik maupun kebudayaan. ${ }^{25}$

Kaum Israel menyesuaikan diri dengan perubahan-perubahan yang begitu besar, walupun banyak kelompok yang juga tidak terkena pengaruh-pengaruh baru, tetapi tetap menganggap segala perkembangan itu sebagai unsur-unsur asing. Kelompok-kelompok demikian itu ternasuk orang desa, orang padang gurun, dan juga orang kota. Zaman emas yang singkat itu, sangat memperkaya hidup rohani dan hidup mental di Israel, serta mengembangkan kebudayaan, kesenian, dan filsafat. Berdasarkan perkembangan itu Yahweh dipandang sebagai Tuhan seluruh umat manusia. Yahweh menjadi sumber hikmat dan providentia. ${ }^{26}$

\section{Pasca pembuangan}

Pada tahun 721 SM Samaria, ibu kota Israel utara, jatuh ke tangan pasukan Asyur dan umatnya terpencar-pencar (1Raja-raja 17). Banyak di antara mereka diangkut ke Asyur dan negara-negara lain. Setelah itu di tahun 587 SM raja Nebukadnezar merebut dan menghancurkan kota Yerusalem, dan bersamaan dengan itu berakhirlah kerajaan Yehuda (2 Raja-raja 25). Sebagian rakyat mati terbunuh, sebagian dijadikan tawanan perang dan dibawa ke Babel dan hanya yang paling miskin yang ditinggalkan di Yehuda.

Orang Israel kehilangan seluruh harta kekayaan mereka dalam pembuangan. Para pembesar ditawan dan dibawa ke Asyur dan babel dan dalam keadaan terpaksa meninggalkan tanah milik pusaka mereka di Palestina, sedangkan tentara yang menawan mereka merenggut semua harta milik mereka. Hanya para petani yang ditinggalkan untuk terus menyambung hidup di tanah yang sudah dijarah, sebagaian melarikan diri ke Mesir demi mengharapkan nasib yang jauh lebih baik.

Kemungkinan lain bisa terjadi, misalnya ada orang yang membelot kepada pihak Babel dengan memanfaatkan situasi tersebut demi kepentingan untuk memperoleh keuntungan (2 Raja-raja 25:11). Di lain pihak dari antara orang-orang buangan Israel tersebut ada yang berhasil di dlam perdagangan, bahkan mendapat pendidikan di negeri asing serta memperoleh jabatan tertentu di dalam pemerintahan seperti Ester, Daniel, Nehemia. Tentunya orang berbakat seperti ini dimanapun bisa berhasil, sehingga tidak dapat dikatakan peristiwa pembuangan itu semata-mata sebagai malapetaka terbesar dalam seluruh sejarah Israel sebagai bangsa.

\footnotetext{
${ }^{25}$ Sri Wismoady Wahono, Disini Kutemukan (Jakarta: BPK Gunung Mulia, 1986).139

${ }^{26}$ Vriezen, Agama Israel Kuno.190-191
} 
Pada tahun-tahun berikut sekitar tahun 538, dan pada tahun-tahun berikutnya, sekelompok orang Israel memperoleh kesempatan untuk kembali ke tanah air mereka (Ezra 1 dst). Wilayah Yehuda di bagian selatan Palestina, dijadikan propinsi kerajaan Persia dan Raja Koresy mengijinkan orang-orang yang pulang untuk membangunnya kembali. Kebebasan diberikan kepada orang-orang Yehuda dalam budaya dan agama, walaupun secara politik mereka takluk pada Persia. Namun sangat disayangkan penindasan dan ketidakadilan timbul kembli sesudah mereka kembali kesana untuk membangun kembali bangsa mereka (Nehemia 5:1-5; Yesaya 58:1-12; Maleakhi 3:5).

Di awal sejarah Israel Alkitab tidak membicarakan bagaimana orang dibayar dalam melakukan pekerjaannya, sehingga sulit untuk menentukan untuk jenis pekerjaan tertentu apakah mendapatkan bayaran (Kejadian 29, 15; Mikha 3, 11). Kemungkinannya mereka beberapa orang dengan jenis pekerjaan tertentu dibayar dengan makanan atau barang.Di masa raja-raja, beberapa orang dibayar dengan emas atau perak. Sekitar tahun 600 SM, Kekaisaran Persia diketahui mulai membuat koin sebagai alat tukar dan membayar pekerja.

Keadaan social di Yehuda sangat bobrok dan tidak menyukakan Allah, disebabkan oleh kehidupan orang-orang Yehuda tidak sesuai kehendak Allah yang puncaknya Yehuda ditaklukkan oleh Babel.

Menurut ulasan Groenen, Israel sedang dilanda krisis politik, ekonomi dan agama pada saat tampilnya nabi Yesaya. Dimana pada saat itu bangsa kekuasaan politik terbesar dikuasai oleh Asyur yang ibukotanya adalah Niniwe (daerah Mesopotamia). Pada masa itu kerajaan Israel utrara masih berdiri kokoh, sejahtera dan makmur. Namun masa kelimpahan tersebut juga bersamaan dengan kemerosotan akhlak, ketidakadilan, pemerasan terhadap rakyat kecil oleh kalangan atas yang merajalela. Nabi Yesaya di kerajaan Yehuda mengecam kemerosotan itu dan mengemukakan ancaman hukuman Allah. Ancaman itu bukanlah omong kosong, sebab kerajaan Asyur sedang berkembang pesat di bawah pimpinan TiglatPileser III. Yesaya menurutkan kecaman dan ancaman seperti yang dicatat di dalam pasal 1-5, termauk nubuat-nubuat lain yang ditujukan kepada Yehuda.. ${ }^{27}$

Groenen kemudian menyebutkan bahwa pokok pemberitaan Yesaya adalah tentang kekudusan Allah. ${ }^{28}$ Yesaya berupaya menyadarkan seluruh umat tidak henti-hentinya akan kebesaran serta kekudusan Allah dalam pewartaannya. Yesaya dengan tegas berkata kepada raja Ahas dan Hizkia untuk percaya kepada Tuhan secara mutlak bukan hanya dalam bidang kerohanian namun juga secara politik. ${ }^{29}$ Latar belakang social seperti inilah yang membuat Yesaya dipakai Allah pada untuk membawa kembali umat Israel ke jalan Allah.

Yesaya memulai panggilan pelayanannya sejak matinya raja Uzia di tahun 740 SM sampai dengan Hizkia di tahun 687 SM, masa pelayanannya meliputi setenah abad sejarah

\footnotetext{
${ }^{27}$ Achim Teschner, Rangkaian Visi Mutiara Kitab Yesaya (Jakarta: Yayasan Komunikasi Bina Kasih, 2002). 15

${ }^{28}$ Ibid. 16

${ }^{29}$ Ibid. 17
} 
Yehuda. Yesaya Bin Amos adalah seorang keturunan Yehuda yang berasal dari Yerusalem. Akhir hidup dari Yesaya menurut cerita tradisi Yahudi, Yesaya dikatakan mati syahid digergaji menjadi dua oleh raja Manasye putra Hizkia yang jahat dan penggantinya pada tahun 680 SM. ${ }^{30}$ Yesaya seorang yang berpendidikan serta berasal dari keluarga kalangan atas di Yerusalem dan memiliki bakat sebagai seorang pengubah syair. Yesaya juga dianggap sebagai nabi yang paling memahami kesusastraan sert merupakan nabi yang paling berpengaruh dari semua nabi-nabi yang menulis kitab. Yesaya juga diketahui mengenal baik kaluarga kerajaan, hal itu ditunjukkan oleh begitu mudahnya Yesaya memasuki kerajaan sehingga sering diduga bahwa ada hubungan kekeluargaan antara Yesaya dengan keluarga kerajaan, Yesaya dengan tegas memberi nasehat kepada raja dengan nubuatnya mengenai politik luar negeri Yehuda.

Yesaya hidup dalam zaman yang sama dengan Hosea dan Mikha yang bernubuat akan ancaman Asyur dan keruntuhan Israel Utara serta kebobrokan moral bangsa Yehuda. Yesaya menerima panggilannya sebagai nabi ketika ia beribadah di Bait Allah Yerusalem. Panggilan Allah kepadanya sangat menekankan pemahaman Yesaya mengenai Allah sebagai Raja Israel. ${ }^{31}$ Kesadaran tersebut terlihat begitu kentara pada saat pemujaan dan pengagungan orang-orang Israel atas kuasa Allah yang besar dalam perayaan musim gugur. Dari awal keterpanggilan dan seiring panggilan tersebut Tuhan memberikan tugaskepada Yesaya untuk memperingatkan kepada bangsa Israel mengenai malapetakan besar yang akan dating menimpa bangsa itu. Hal itu memiliki pengertian bahwa kota-kota dan seluruh tanah Yehuda akan dibumi-hanguskan dan Yehuda akan mengalami kekalahan militer. Dari pemberitaan dan peringatan nabi Yesaya kala itu tampak bahwa Allah begitu murka atas Yehuda oleh karena ketidaktaatan mereka kepada Allah. Oleh karena kondisi social Yehuda dari ketetapan Allahlah Yesaya dipanggil menjadi nabi.

Pada masa pelayanan Yesaya keadaan politik dan keadaan ekonomi tidak terpisahkan dari antara kerajaan Israel Utara dan Yehuda, tetapi keadaan itu berbanding terbalik dengan keadaan sebelumnya yang terbilang makmur serta maju karena memang kerajaan itu terletak secara strategis dan berada di jalur perdagangan yang sangat ramai dan keadaan ini justru yang membuat Israel lupa atas identitas mereka yang sebenarnya dan membuat mereka terlena sehingga jauh dari Tuhan karena kesombongan orang-orang Israel tetapi ketika terjadi perang saudara dengan Yehuda yang kala itu memiliki hubungan dengan Asyur membuat mereka terpaksa untuk berperang kemudian tidak diketahui lagi sejak kejatuhan Israel tahun 722 SM oleh Asyur. Sedangkan Yehuda pada masa pemerintahan Uzia sangat menikmati kemakmuran. Hal tersebut terjadi dikarenakan oleh menyurutnya kerajaan Aram dan ketiadaan campur tangan Asyur di wilayah mereka dalam rentang waktu yang lama. Diduga pada masa-masa seperti itulah Yesaya bekerja dan melalui peristiwa-peristiwa penting dalam kemakmuran Yehuda dan sejarah Israel. Namun

\footnotetext{
${ }^{30}$ Alkitab Penuntun Hidup Baru (Bogor: Lembaga Alkitab Indonesia, 2008).1037

${ }^{31}$ Wahono, Disini Kutemukan.165
} 
keadaan itu tidak bertahan lama oleh karena krisis politik yang dialami Yehuda dimana Asyur mulai memperluas daerah kekuasannya dengan begitu aktif. Yehuda harus siap siaga berperang terhadap Asyur sementara pada waktu itu sedang dalam kondisi krisis politik yang berdampak pada keadaan ekonominya. Yehuda dan Asyur mengikat perjanjian kerja yang memaksakan pembayaran upeti kepada Asyur karena posisi Asyur pada waktu itu merupakan salah satu kerajaan terkuat dan banyak menguasai kerajaan-kerajaan lain termasuk kerajaan Israel utara. Yesaya menegur raja Ahas karena sebelumnya bersandar kepada Asyur dalam menaklukkan Israel utara, Yesaya memperingatkan supaya raja Ahas tidak bersekutu dengan bangsa lain namun hal itu ternyata tidak diindahkannya. Ahas tetap meminta pertolongan Asyur dan menolak nasihat yang diberikan oleh Yesaya. ${ }^{32}$ Yesaya memiliki pengaruh yang terbesar hanya pada masa pemerintahan raja Hizkia. ${ }^{33}$ Oleh karena hubungan Yehuda dengan Asyur menimbulkan penambahan pengeluaran negara. Sementara keadaan ekonomi Yehuda bergantung kepada peternakan dan pertanian selain itu mengandalkan pekerjaan lainnya seperti tambang dan perdagangan namun dalam keterbatasan sedangkan Yehuda harus bersiap-siap jika terjadi serangan-serangan dari bangsa lain, hal inilah yang menyebabkan krisis pada waktu itu. Oleh karena itu kehadiran Yesaya muerupakan peringatan kepada orang-orang Yehuda oleh karena ketidakadilan yang merajalela, yang menimbulkan penderitaan kepada rakyat dan menyebabkan kerusakan moral orang-orang Yehuda dan menjauh dari ketetapan Allah.

Keadaan ini semakin memburuk ketika Babel mengalahkan Asyur, banyak kerajaan yang ditaklukkan oleh Babel sehingga kekuatannya semakin besar. Juga pada waktu itu Babel menyerang dan mengalahkan Yehuda. Babel menghancurkan kota-kota Yehuda bahkan bait Allah sendiri juga tidak luput dari penghancuran tersebut dan orangorang Yehuda menjadi tawanan dan dibawa ke Babel sebagai orang buangan. Ada tiga gelombang yang tercatat masuknya para tawan Yehuda ke Babel, sedikitnya tercatat 4.600 orang di antara tahun 598 dan 582 SM. $^{34}$ Kebanyakan diantaranya adalah laki-laki yang terhitung dalam jumlah tersebut serta anggota keluarga mereka juga ditawan ke Babel. Kebanyakan diantara orang buangan itu merupakan golongan atas di Yerusalem dan negeri sekitarnya seperti para imam, bangsawan, pegawai tinggi, ditambah beberapa ratus ahli dan tukang serta para tuan tanah. Mereka diijinkan membangun tempat tinggal, memelihara agama, berdagang, bertani sebaga usaha untuk melanjutkan hidup selama dalam pembuangan. Meski keadaan ekonomi pada waktu itu tidak dijelaskan, namun dilihat dari keadaan orang-orang Yehuda mengalami tekanan terlebih karena mereka menjadi orang asing dan jauh dari tanah kelahiran mereka di Yerusalem. Kehidupan mereka semakin sulit ketika diharuskan bekerja rodi pada waktu tertentu dan wajib patuh terhadap perintah para

\footnotetext{
${ }^{32}$ S H Widyapranawa, Kitab Yesaya (Jakarta: BPK Gunung Mulia, 2003).257

${ }^{33}$ Alkitab Penuntun Hidup Berkelimpahan (Jakarta: Lembaga Alkitab Indonesia, 2003). 1037

${ }^{34}$ Marie-Claire Barth, Tafsiran Alkitab : Kitab Yesaya Pasal 40-55 (Jakarta: BPK Gunung Mulia, 1983).11
} 
penguasa Babel. Oleh sebab itu mereka mulai mengidam-idamkan pembaharuan dengan menantikan penolong bagi mereka.

Dalam penantian bangsa Israel dalam pembuangan inilah tampil nabi Yesaya yang para ahli meragukan bahwa Yesaya yang muncul pada masa pembuangan ini apakah sama dengan Yesaya yang tampil sebelum pembuangan. Karena nabi yang tampil dalam pembuangan tidak pernah disebutkan namanya kecuali satu kali disinggung dalam pemanggilannya (40:6-8). Orang Yehuda mengalami penderitaan selama 40 Tahun dalam pembuangan sehingga jaminan yang Allah berikan kepada mereka sebagai berkat turuntemurun hilang dan kota suci merekapun hancur. Sebagaimana dengan pemberitaan nabi Yesaya mengenai hukuman Allah yang dijatuhkan kepada umat pilihan yang melanggar kehendak-Nya. Yesaya mengobarkan kembali keyakinan akan Allah dengan memperingatkan kembali kedaulatan Allah sebagai khalik, kebaikan hati Allah yang menetapkan Abraham dan keturunannya sebagai pilihan, Kasih karunia-Nya dalam pembebasan Israel dari Mesir ${ }^{35}$. Pada Zaman ini Yesaya lebih cenderung memberikan dorongan beserta harapan oleh karena penderitaan dan tekanan dari penguasa Babel yang dialami orang Israel sebagai orang buangan di Babel, sekalipun dalam pemeliharaan keagamaan mereka mendapat ijin tetapi selalu merindukan Yerusalem. Yesaya mampu membangkitkan kepercayaan bangsa Israel kepada Tuhan dalam keadaan yang demikian, hingga kemudian seorang raja Persia yang bernama Koresy bangkit dan menaklukkan Babel serta menjadi Penguasa pada waktu itu. Orang buangan diijinkan oleh raja Koresy kembali ke negeri mereka masing-masing pada tahun 538 termasuk orang-orang Yehuda kembali ke Yerusalem dengan untuk mendirikan kembali kota-kota dan Bait Allah kembali di Yerusalem.

Sekembalinya dari pembuangan keadaan ekonomi Yehuda membaik sedikit demi sedikit, di tahun-tahun berikutnya orang-orang mulai merencanakan pembaharuan sekelompok demi kelompok karena pengembalian harta benda bait Allah yang dilakukan oleh Raja Koresy serta pemberian ijin kepada orang Israel untuk pembangunan kembali tembok-tembok kota. Namun pembangunan masih belum dapat terselesaikan disebabkan oleh kepetingan pribadi. Orang miskin terlantar sementara yang berkecukupan hanya membangun rumah-rumah mereka sendiri. Pada masa itu rencana pembangunan menjadi terhambat karena ketidakstabilan politik dan ekonomi sampai kepada pemerintahan Raja Darius. Pekerjaan pembangunan bait suci itu pada akhirnya selesai pada tahun 515 SM, setelah persatuan kembali orang-orang Yehuda yang dilakukan oleh Hagai dimana sebelumnya pekerjaan itu telah dimulai sejak tahun $520 \mathrm{SM}^{36}$ Namun hal itu tidak sesuai dengan pengharapan para nabi karena para imam yang menyalahgunakan kedudukan mereka, rakyat diajak berbakti kepada dewa-dewa dan pembayaran pajak agama dianggap remeh. Pada masa-masa yang gelap seperti inilah Yesaya Tuhan bangkitkan sebagai nabi

\footnotetext{
${ }^{35}$ Ibid. 15

${ }^{36}$ Marie-Claire Barth, Tafsiran Alkitab KITAB YESAYA Pasal 56-66 (Jakarta: BPK Gunung Mulia, 1994).1
} 
untuk menyampaikan firman-Nya, ia membawa ajaran supaya bangsa Yehuda kembali kepada Tuhan serta mengingatkan umat Tuhan untuk terus percaya kepada Allah.

Selama berada di pembuangan Babel, orang-orang Yehuda tidak menderita seperti keadaan mereka dulu di Mesir. Dalam nasehatnya, Yeremia menegur bangsa Israel untuk tetap bekerja, mendirikan rumah, serta mengusahakan kesejahteraan Babel hingga masa 70 tahun berakhir (Yeremia 11:1-10). Bahkan beberapa orang mendapatkan posisi yang strategis dalam pemerintahan Babel (Daniel 2:48). Saat itu Babel dikuasai oleh Persia, keadaan itu masih tetap tidak mengalami perubahan. Sejumlah orang Israel masih tetap memiliki posisi yang penting dalam kerjaaan Persia, seperti Ester (Ester2:17), Zerubabel (Hagai 1:1, Ezra (Ezra 7:6), Nehemia (Nehemia 8:9).

\section{KESIMPULAN}

Dalam penjelasan artikel ini, penulis mengambil kesimpulan sebagai berikut. Pertama, panggilan Allah kepada bangsa Israel awalnya merupakan panggilan beribadah sebagai umat-Nya. Kedua, Allah menginginkan kekhususan dan keunikan perbedaan dalam hal keagamaan bagi bangsa Israel secara berbeda dengan bangsa-bangsa lain di sekitarnya, hal ini juga ditunjukkan oleh symbol-simbol liturgy dan kehidupan keagamaan sebagai Legal Corpus kitab perjanjian, artinya Allah menjadikan bangsa Israel sebagai subyek dari segala kehendak Allah dalam setiap bidang kehidupan, termasuk dalam hal perniagaan dan kepemilikan harta benda. Ketiga, fenomena sinkritisme juga meresap dalam kehidupan keagaman Israel pada saat itu yang berakibat kepada dekadensi rohani yang mempengaruhi mulai dari pemimpin sampai kepada umat yang secara mencolok terlihat dengan kebangkitan monarki pembaharuan secara mendasar dan menyeluruh terkait system peribadahan kepada Allah dan system kemasyarakatan umat dalam pemerintahan Yosia. Tentunya pesan ini bukan hanya berlangsung di zaman Israel namun juga tetap relevan hingga di masa kini.

\section{KEPUSTAKAAN}

Asher, Michael, and Mariantonietta Peru. The Last of the Bedu : In Search of the Myth. New York: Penguin, 1997.

Baker, David L. Mari Mengenal Perjanjian Lama. Jakarta: BPK Gunung Mulia, 2013. Barfield, Thomas Jefferson. The Nomadic Alternative. Amerika Serikat: Prentice Hall, 1993.

Barth, Marie-Claire. Tafsiran Alkitab : Kitab Yesaya Pasal 40-55. Jakarta: BPK Gunung Mulia, 1983.

—. Tafsiran Alkitab KITAB YESAYA Pasal 56-66. Jakarta: BPK Gunung Mulia, 1994. Bright, John. A History of Israel. London: SCM Press, 1972.

Davis, John Jefferson. Theology Primer. Grand Rapids: Baker Book House, 1981.

Elmer A Martens. God's Design: A Focus on Old Testament Theology. Grand Rapids:

Baker Book House, 1981.

England, John C. Living Theology in Asia. London: SCM Press, 1981. 
Gundry, Stanley N, and Alan F Johnson. Tensions in Contemporary Theology. Grand Rapids: Baker Book House, 1976.

Hardjoatmodjo, Ignatius Suharyo. Mengenal Alam Hidup Perjanjian Lama. Yogyakarta: Kanisius, 1993.

Hinson, David F. Sejarah Israel Pada Zaman Alkitab. Jakarta: BPK Gunung Mulia, 2015.

Lasor, W S, F W Bush, D A Hudbard, and Warner Tan. Pengantar Perjanjian Lama : Jil. 1 Taurat Dan Sejarah. Jakarta: BPK Gunung Muliah, 1993.

Michigan, Universitas. The World of The Bible. Edited by A. S. van der Woude and M. J. Mulder. Wm. B. Eerdmans Publishing Company, 1986.

Millard, Alan R, and Donald J Wiseman. "Essays on the Patriarchal Narratives." Leicester: Inter-Varsity Press, 1980.

OFM, C Groenen. Pengantar Ke Dalam Perjanjian Lama. Yogyakarta: Kanisius, 1992.

Prestia. Himpunan Bahan Study Institute: Contextual Exegesis Di Ujung Pandang. Ujung Padang, 1980.

Teschner, Achim. Rangkaian Visi Mutiara Kitab Yesaya. Jakarta: Yayasan Komunikasi Bina Kasih, 2002.

Verkuly, Johannes. Contemporary Missiology. Grand Rapids: Wm. B. Eerdmans Publishing Company, 1978.

Vriezen, Theodorus Christiaan. Agama Israel Kuno. Jakarta: BPK Gunung Mulia, 1967. Wahono, Sri Wismoady. Disini Kutemukan. Jakarta: BPK Gunung Mulia, 1986.

Widyapranawa, S H. Kitab Yesaya. Jakarta: BPK Gunung Mulia, 2003.

Wiseman, Donald John. They Lived in Tents in Biblical and Near Eastern Studies. Grand Rapids: Wm. B. Eerdmans Publishing Company, 1978.

Alkitab Penuntun Hidup Baru. Bogor: Lembaga Alkitab Indonesia, 2008.

Alkitab Penuntun Hidup Berkelimpahan. Jakarta: Lembaga Alkitab Indonesia, 2003. 